\title{
The Research on Venture Capital's Effect on Earnings Management of Listed Companies of GEM before IP0: Evidence from China
}

\author{
Ruting Feng \\ Management School, Jinan University, Guangzhou, China \\ Email: rutingfeng@126.com
}

Received 6 May 2015; accepted 22 May 2015; published 26 May 2015

Copyright (C) 2015 by author and Scientific Research Publishing Inc.

This work is licensed under the Creative Commons Attribution International License (CC BY).

http://creativecommons.org/licenses/by/4.0/

cC) (7) Open Access

\begin{abstract}
This article selects IPO firms of China GEM in 2009-2014 as the research object, using cross sectional modified Jones model to measure accrued earnings management, with the multiple regression method to discuss the effect of venture capital (VC) on earnings management before IPO. It shows that there is negative correlation between single VC and the earnings management before IPO, but no significant correlation between joint VC and the earnings management before IPO. This result is robust. In conclusion, single VC plays the role of certification and monitoring. While because of the incompleteness of the contracts, there are conflicts in the joint VC. It prevents joint VC from inhibiting the action of the earnings management.
\end{abstract}

\section{Keywords}

China GEM, Accrual Earnings Management, Venture Capital

\section{Introduction}

Accounting earnings is always the focus of attention. Patell (1989) pointed out that the accounting earnings will affect the equity capital market, debt capital market, labor market, the material product market, the political market and so on [1]. Accounting earnings is not only a number, but also will have economic consequences, affecting the distribution of interests of stakeholders. In the case of information asymmetry, whether the disclosure of earnings information is truly reflecting the reality of the company has become a question. Due to various reasons, managers are likely to manage the earnings.

Earnings management will bring a series of consequences. Teoh, Wong, Rao (1998) provides evidence that issuers with unusually high accruals in the IPO year experience poor stock return performance in the three years 
after [2]. Positive accruals before IPO will reduce the subsequent return. In china, Zhang Zongyi and Wang Xinjian (2003) investigated IPO companies in China during 1998-2000, found out that there were earnings management in the year before IPO, of IPO and after IPO [3]. Thus, earnings management will affect later performance. So how to reduce the information asymmetry, restrain earnings management is worth thinking about.

Growth Enterprises Market (GEM) was listed in 2009 in China. With the launch of the GEM, venture capital is also developing rapidly. In China, before 2009, venture capital developed slowly. But after 2009, the rapid growth of venture capitals presented. Compared with 2009, the scale of VC has increased more than five times in 2011. With the development of venture capital, scholars begin to pay close attention to the research of venture capital, specially the effect of venture capital on earnings management.

This article selects IPO companies of GEM in China from 2009 to 2014 as the research object, using cross sectional modified Jones model to measure accrued earnings management, with the multiple regression method to discuss the effect of VC on earnings management before IPO.

\section{The Role of Venture Capital and Hypothesis of This Paper}

\subsection{VC Monitoring Hypothesis}

Under the VC monitoring hypothesis, venture capital will provide professional services about management to the company and add value to the company. In terms of governance structure, through active participation in company' board, venture capital plays an important role in the company's board of directors and provides service to perfect the corporate governance structure in order to strengthen the supervision and reduce the possibility of earnings management. At the same time, the venture capital will make suggestions about company's strategy, human resource, finance, product and so on (Gorman and Sahlman, 1989) [4]. VC can improve the financing environment for the company or provide financial support, improve company's intrinsic value, help IPO firms to establish a good profitability. Venture-backed IPO firms' under-pricing rate is lower and the subsequent performance is more active (Barry et al., 1990 [5]; Jain and Kini, 1995 [6]; Campbell and Frye, 2009 [7]; Chahine and Filatotchev, 2008 [8]).

\subsection{VC Certification Hypothesis}

Venture capital certification hypothesis believes that VC can play the certification role. There is asymmetric information between internal and external investors, insider is in the superiority side. External stakeholders is in the inferior side. Internal managers will hide the "bad news" of the IPO firm in order to get a "good IPO price". As a result, the reason external investors will pay a lower price. Venture capital as a "third-party” investing in the IPO firms can transfer signal that the IPO firms is a potential one and reduce the asymmetric information, reduce the possibility of earnings management (Megginson and Weiss,1991 [9]; Lin and Smith,1998 [10]; Francis and Hasan, 2001 [11]).

\section{Hypothesis of This Paper}

There are evidences about earnings management during the period of IPO in China (Wang Chunfeng and Li Jidong, 2003 [12]; Zhang Zongyi and Huang xinjian, 2003; Wang Zhiqiang and Liuxing, 2003 [13]; Caichun et al., 2013 [14]; Qi Huanjin and Huang Youwei, 2014 [15]). The GEM as a platform to promote the development of high-tech companies, attracts a lot ofventure capital. Gorman and Sahlman (1989) stand for that VC provides professional services about finance, strategy, management, human resource and so on. Amit, Brander, Zott (1998) agree that venture capital has the ability to reduce the cost of informational asymmetries [16]. Arthurs and Busenitz (2006) test a match-pair sample of VC-backed and non-VC-backed new ventures and find that VCbacked ventures demonstrate greater dynamic capabilities as they relate to product and management development [17].

Venture capital will participate in the board of directors of the company, improve company's management level and perfect the corporate governance structure (Barry et al., 1990; Campbell and Frye, 2009). This suggests that venture capital plays a role of the certification and monitoring, will provide services for company in most aspects, perfecting the corporate governance structure, help to reduce the degree of information asymmetry, reduce the probability of earnings management. Hochberg (2004) [18], Morsfield and Tan (2006) [19], Gioielli and Carvalho (2008) [20]; Agrawal and Cooper (2010) [21]; Chen Xiangyou (2010) [22]; Lee and Masulis 
(2011) [23] found that there is less earnings management and better financial information in VC-backed IPO firms. Venture capital can play the role of monitoring and certification. As such, we argue that venture capital can reduce the earnings management.

Hypothesis 1: Venture capital can paly the role of monitoring and certification. That is to say compared with non-VC backed IPO firms, there is lower earnings management in VC-backed IPO firms.

Because VCs often syndicate their investments, however, the effect of any single VC firm on earnings management in an IPO may be uncertain (Lerner, 1994) [24]. Sorenson and Stuart (2008) argue that with large numbers of diverse members there are less potential reputation effects because it is harder to tell what a member's contribution to the network [25]. Syndication diversity also creates a situation where the individual interests among the VCs in the syndicate may diverge (Filatotchev et al., 2006) [26] and where information asymmetries may result in potential conflicts of interest between lead and other syndicate members (Cumming, 2006) [27]. Chahine et al. (2012) used a matched sample of 274 VC-backed IPOs in the US and the UK, it shows that the diversity of a VC syndicate increases pre-IPO discretionary current accruals, used as a proxy for earnings management [28]. In this paper, we ague that because of the incompleteness of the contracts in the joint venture capitals, there are conflicts in the joint VC. It prevents joint VC from inhibiting the action of the earnings management.

Hypothesis 2a: Single-venture capital can play the role of monitoring and certification. That is to say compared with non-single venture backed IPO firms, there is significant lower earnings management in single venture backed IPO firms.

Hypothesis 2b: joint venture capital can not play the role of monitoring and certification because of the incompleteness of the contracts. That is to say compared with non-VC-backed IPO firms, there is no significant lower earnings management in. joint-VC-backed IPO firms.

\section{Data and Methodology}

\subsection{Model}

For hypothesis 1, the full sample is divided into two parts: VC-backed sample and non VC-backed sample, using Equation (1); for hypothesis 2, the sample is divided into three parts: VC-backed sample, single VC-backed sample (when there is only one venture capital in the IPO firms) and joint VC-backed sample (when there is more than one venture capital in the IPO firms, using Equation (2) and Equation (2).

To use relevant methods to measure accrued earnings management as the dependent variable and choose Certified public accountants firms, underwriters, asset-liability ratio, revenue growth, company total assets, cash flow ratio as control variables.

$$
\begin{aligned}
\mathrm{AEM}= & \beta_{0}+\beta_{1} \mathrm{VC}+\beta_{2} \mathrm{AUDIT}+\beta_{3} \mathrm{UW}+\beta_{4} \mathrm{LEV}+\beta_{5} \mathrm{GROWTH}+\beta_{6} \mathrm{SIZE} \\
& +\beta_{7} \mathrm{CASH}+\text { year dummy }+ \text { industry dummy } \\
\mathrm{AEM}= & \beta_{0}+\beta_{1} \mathrm{SNGLE}+\beta_{2} \mathrm{UNION}+\beta_{3} \mathrm{AUDIT}+\beta_{4} \mathrm{UW}+\beta_{5} \mathrm{LEV}+\beta_{6} \mathrm{GROWTH} \\
+ & \beta_{7} \mathrm{SIZE}+\beta_{8} \mathrm{CASH}+\text { year dummy }+ \text { industry dummy } \\
\mathrm{AEM}= & \beta_{0}+\beta_{1} \mathrm{UNION}+\beta_{2} \mathrm{AUDIT}+\beta_{3} \mathrm{UW}+\beta_{4} \mathrm{LEV}+\beta_{5} \mathrm{GROWTH} \\
& +\beta_{6} \mathrm{SIZE}+\beta_{7} \mathrm{CASH}+\text { year dummy }+ \text { industry dummy }
\end{aligned}
$$

\subsection{Instructions of Variables}

AEM is the accrual based earnings management. In order to measure the accrual based earnings management, we calculate the total acrruls (TA) in Equation (4) first. Then we use the modified Jones model (1995) [29] to measure nondiscretionary accruals (NDA) through Equation (5) and Equation (6). Finally, the accrual earnings management is calculate as Equation (7).

$$
\begin{gathered}
\mathrm{TA}_{\mathrm{i}, \mathrm{t}}=\mathrm{E}_{\mathrm{i}, \mathrm{t}}-\mathrm{CFO}_{\mathrm{i}, \mathrm{t}} \\
\mathrm{TA}_{\mathrm{i}, \mathrm{t}} / \mathrm{A}_{\mathrm{i}, \mathrm{t}-1}=\beta_{1} 1 / \mathrm{A}_{\mathrm{i}, \mathrm{t}-1}+\beta_{2} \mathrm{REV}_{\mathrm{i}, \mathrm{t}-1} / \mathrm{A}_{\mathrm{i}, \mathrm{t}-1}+\beta_{3} \mathrm{PPE}_{\mathrm{i}, \mathrm{t}} / \mathrm{A}_{\mathrm{i}, \mathrm{t}-1} \\
\mathrm{NDA}_{\mathrm{i}, \mathrm{t}}=\beta_{1} 1 / \mathrm{A}_{\mathrm{i}, \mathrm{t}-1}+\beta_{2}\left(\mathrm{REV}_{\mathrm{i}, \mathrm{t}-1}-\mathrm{REC}_{\mathrm{i}, \mathrm{t}-1}\right) / \mathrm{A}_{\mathrm{i}, \mathrm{t}-1}+\beta_{3} \mathrm{PPE}_{\mathrm{i}, \mathrm{t}} / \mathrm{A}_{\mathrm{i}, \mathrm{t}-1}
\end{gathered}
$$




$$
\mathrm{AEM}=\mathrm{TA}_{\mathrm{i}, \mathrm{t}} / \mathrm{A}_{\mathrm{i}, \mathrm{t}-1}-\mathrm{NDA}_{\mathrm{i}, \mathrm{t}}
$$

where $\mathrm{TA}_{\mathrm{i}, \mathrm{t}}$ is the total acrruls; $\mathrm{E}_{\mathrm{i}, \mathrm{t}}$ is the is the operating earnings; $\mathrm{CFO}_{\mathrm{i}, \mathrm{t}}$ is the operating cash flows; $\mathrm{A}_{\mathrm{i}, \mathrm{t}-1}$ is total assets in the last period; $R E V_{i, t}$ is change in revenues; $\mathrm{PPE}_{\mathrm{i}, \mathrm{t}}$ is gross value of fixed asset; $\mathrm{REC}_{\mathrm{i}, \mathrm{t}}$ is the change in accounts receivable.

VC is a dummy. If a company is VC-backed, then VC means 1, otherwise it is 0.we consider whether there are venture capitals in the top ten shareholders. First, consistent with Wu Chaopeng et al. (2012) [30]: whether there are related words like venture capital in the name of the top ten shareholders; Further refer to "CHINA VENTURE CAPITAL YEARBOOK” edited by Cheng Siweiin 2013 and China venture capital and private equity investment institutions list issued by Zero2ipo group, at last we search information from the network to decide whether the top ten shareholders is venture capital or not; And eliminate some stock/bond investment fund.

SINGLE is a dummy. If there is only one venture capital in top ten shareholders of the IPO firm, its value is 1 , other with 0 .

UNION is a dummy. If there are more than one venture capital in top ten shareholders of the IPO firm, its value is 1 , other with 0 .

AUDIT is a dummy. If a IPO firm's accounting firm belongs to the top ten accounting firms, then it means 1 , othere wise it is 0 . we calculate the top ten accounting firms according to the average rranking from "accounting firms comprehensive ranking” published by CICPA (The Chinese Institute of Certified Public Accountants) from 2009 to 2013.

UW is a dummy. If a IPO firm's a under writer belongs to the top ten underwriter, then it means 1 , otherwise it is 0 . We calculate the top ten underwriter according to the average ranking from "underwriter comprehensive ranking” published by SAC ( Securities Association of China ) from 2008-2011.

Control variables: From the debt paying ability, the higher the asset-liability ratio of the company, the higher debt levels it has , the more fund it needs, the more likely it is to manage earnings; From the company growth, Morsfield and Tan (2006) think that accrued earnings management and corporate growth has positive correlation. The faster the company growth, the larger capital it requirements, the more likely it is to manipulate earnings management; From the perspective of the assets, Li Xian, Nie LiJie (2006) find that firm size and accrued earnings management has negatively correlation [31]. Morsfield and Tan (2006) find that firm size and accrued earnings management are positive related. On the one hand, the larger the company scale is, the greater the operating space of earnings management is; On the other hand, the greater of the company size, the more it's concerned, the more difficulty it has in implementation of earnings management. From the cash flow ratio, the more cash flow of the company, generally the better surplus quality is. The ratio of cash flow and earnings management is negatively related. Li Xian and Nie LiJie (2006), Chen Xiangyou(2009) and Morsfield and Tan (2006) found out the negative correlation between cash flow and accrued earnings management. As a result, the rate of assets and liabilities of the company, operating income growth, scale, cash flow ratio should be chosen as control variables.

\subsection{Data Source}

This article selects IPO companies in the GEM in 2009-2014 as the research sample, choose the annual report data one year before IPO as the research object, eliminating missing data, in total there are 405 observations. Listed on the gem from 2009 to 2014, there were 36, 117, 128, 73, 0, 51 companies every year. All the Data is from the CSMAR database and the prospectus of the company.

\section{Empirical Results}

\subsection{Descriptive Statistics}

According to Table 1 the mean of AEM, the full sample is 0.092, the sample of VC-backed is 0.088 the sample of non-VC-backed is 0.096 the sample of single VC-backed is 0.076 the sample of joint VC-backed is 0.102 . So there is lower accrual based earnings management in single VC-backed companies.

Compared with the joint VC-backed companies, single VC-backed sample's revenue growth, cash ratio and size is higher, and asset-liability ratio is lower. It means that single venture capital's growth rate is more higher, cash flow is more, size is bigger and liability is less. A preliminary judgment is that the financial situation of single venture capital is better. 
Table 1. Descriptive statistics.

\begin{tabular}{|c|c|c|c|c|c|c|c|c|c|c|}
\hline & AEM & GROWTH & LEV & $\mathrm{CASH}$ & SIZE & VC & UW & AUDIT & SINGLE & UNION \\
\hline Mean (all) & 0.092 & $36.169 \%$ & $38.040 \%$ & $13.154 \%$ & 19.642 & 0.440 & 0.462 & 0.425 & 0.205 & 0.237 \\
\hline Mean (VC-backed) & 0.088 & $37.499 \%$ & $37.303 \%$ & $11.220 \%$ & 19.730 & 1 & 0.567 & 0.433 & 0.461 & 0.539 \\
\hline Mean (non-VC-backed) & 0.096 & $35.126 \%$ & $38.618 \%$ & $14.671 \%$ & 19.572 & 0 & 0.379 & 0.419 & 0.004 & 0 \\
\hline Mean (single VC-backed) & 0.076 & $38.077 \%$ & $36.438 \%$ & $12.469 \%$ & 19.744 & 1 & 0.512 & 0.415 & 1 & 0 \\
\hline Mean (joint VC-backed) & 0.102 & $37.006 \%$ & $38.041 \%$ & $10.152 \%$ & 19.718 & 1 & 0.615 & 0.448 & 0 & 1 \\
\hline Median (all) & 0.069 & $30.970 \%$ & $38.580 \%$ & $12.335 \%$ & 19.587 & 0 & 0 & 0 & 0 & 0 \\
\hline Median (VC-backed) & 0.069 & $31.764 \%$ & $38.189 \%$ & $9.997 \%$ & 19.661 & 1 & 1 & 0 & 0 & 1 \\
\hline Median (non-VC-backed) & 0.070 & $30.431 \%$ & $39.232 \%$ & $14.253 \%$ & 19.505 & 0 & 0 & 0 & 0 & 0 \\
\hline Median (single VC-backed) & 0.064 & $29.575 \%$ & $35.086 \%$ & $12.161 \%$ & 19.644 & 1 & 1 & 0 & 1 & 0 \\
\hline Median (joint VC-backed) & 0.069 & $33.347 \%$ & $38.879 \%$ & $8.234 \%$ & 19.719 & 1 & 1 & 0 & 0 & 1 \\
\hline Std-error (all) & 0.085 & 0.307 & 0.155 & 0.112 & 0.647 & 0.497 & 0.499 & 0.495 & 0.404 & 0.426 \\
\hline Std-error (VC-backed) & 0.077 & 0.303 & 0.152 & 0.104 & 0.603 & 0 & 0.497 & 0.497 & 0.500 & 0.500 \\
\hline Std-error (non-VC-backed) & 0.091 & 0.310 & 0.157 & 0.115 & 0.672 & 0 & 0.486 & 0.494 & 0.066 & 0 \\
\hline Std-error (single VC-backed) & 0.054 & 0.338 & 0.153 & 0.105 & 0.633 & 0 & 0.503 & 0.496 & 0 & 0 \\
\hline Std-error (joint VC-backed) & 0.100 & 0.272 & 0.151 & 0.103 & 0.579 & 0 & 0.489 & 0.500 & 0 & 0 \\
\hline Minimum (all) & 0.001 & $-23.641 \%$ & $1.779 \%$ & $-25.256 \%$ & 18.043 & 0 & 0 & 0 & 0 & 0 \\
\hline Minimum (VC-backed) & 0.001 & $-23.641 \%$ & $1.779 \%$ & $-11.878 \%$ & 18.386 & 1 & 0 & 0 & 0 & 0 \\
\hline Minimum (non-VC-backed) & 0.001 & $-18.412 \%$ & $4.645 \%$ & $-25.256 \%$ & 18.043 & 0 & 0 & 0 & 0 & 0 \\
\hline Minimum (single VC-backed) & 0.002 & $-16.772 \%$ & $1.779 \%$ & $-11.380 \%$ & 18.576 & 1 & 0 & 0 & 1 & 0 \\
\hline Minimum (joint VC-backed) & 0.002 & $-23.641 \%$ & $6.234 \%$ & $-11.878 \%$ & 18.386 & 1 & 0 & 0 & 0 & 1 \\
\hline Maximum (all) & 0.572 & $232.174 \%$ & $76.447 \%$ & $50.795 \%$ & 21.779 & 1 & 1 & 1 & 1 & 1 \\
\hline Maximum (VC-backed) & 0.491 & $200.635 \%$ & $74.807 \%$ & $42.490 \%$ & 21.751 & 1 & 1 & 1 & 1 & 1 \\
\hline Maximum (non-VC-backed) & 0.572 & $232.174 \%$ & $76.447 \%$ & $50.795 \%$ & 21.779 & 0 & 1 & 1 & 1 & 0 \\
\hline Maximum (single VC-backed) & 0.223 & $200.635 \%$ & $74.807 \%$ & $41.970 \%$ & 21.751 & 1 & 1 & 1 & 1 & 0 \\
\hline Maximum (joint VC-backed) & 0.545 & $149.001 \%$ & $64.729 \%$ & $42.490 \%$ & 21.498 & 1 & 1 & 1 & 0 & 1 \\
\hline
\end{tabular}

\subsection{Venture Capital and Accrual Earnings Management}

According to Table 2, compared with the non-VC-backed sample, accrual earnings management of the VCbacked sample is not significant lower. Compared with the non-single-VC-backed sample, accrual earnings management of the VC-single-backed sample is significant lower (at the $5 \%$ level or higher).

Take the multicollinearity into consideration, we use Variance Inflation Factor (VIF) to test. From table, the VIF of the variables all are less than 2, so we can believe that there is no multicollinearity in the model. Details as Table 3.

\subsection{Further Robustness Tests}

We choose the Jones (1991) model [32] and Kothari et al. (2005) [33] performance-matched model to measure accrual earnings management as the proxies. Details are as Table 4.

According to Table 4, it can drop the same conclusion of the two proxies which are regressed by using the Jones' Model or the performance-matched Jones' Model to measure the accrued earnings management. 
Table 2. Venture capital and accrual earnings management.

\begin{tabular}{|c|c|c|c|}
\hline & \multicolumn{3}{|c|}{ AEM: modified Jones model (1995) } \\
\hline & Equation (1) & Equation (2) & Equation (3) \\
\hline VC & -0.012 & & \\
\hline (T statistic) & $(-1.53)$ & & \\
\hline SINGLE & & $-0.023^{* *}$ & \\
\hline (T statistic) & & $(-2.51)$ & \\
\hline UNION & & -0.004 & -0.004 \\
\hline (T statistic) & & $(-0.34)$ & $(-0.36)$ \\
\hline AUDIT & 0.001 & 0.001 & 0.001 \\
\hline (T statistic) & $(0.16)$ & $(0.12)$ & $(-0.03)$ \\
\hline UW & 0.003 & 0.002 & 0.001 \\
\hline (T statistic) & $(0.34)$ & $(0.26)$ & $(0.03)$ \\
\hline SIZE & -0.011 & -0.010 & -0.007 \\
\hline (T statistic) & $(-1.05)$ & $(-1.00)$ & $(-0.58)$ \\
\hline GROWTH & $0.047^{* * *}$ & $0.047^{* * *}$ & $0.049^{* *}$ \\
\hline (T statistic) & $(2.63)$ & (2.69) & $(2.17)$ \\
\hline LEV & -0.015 & -0.016 & 0.001 \\
\hline (T statistic) & $(-0.39)$ & $(-0.40)$ & $(-0.01)$ \\
\hline CASH & -0.081 & -0.075 & -0.056 \\
\hline (T statistic) & $(-1.12)$ & $(-1.03)$ & $(-0.65)$ \\
\hline Constant & $0.335^{*}$ & $0.327^{*}$ & 0.329 \\
\hline (T statistic) & $(1.74)$ & $(1.70)$ & $(1.42)$ \\
\hline Number of Observations & 405 & 405 & 323 \\
\hline $\mathrm{R}^{2}$ & 0.116 & 0.121 & 0.135 \\
\hline Adjusted R-squared & 0.072 & 0.075 & 0.081 \\
\hline
\end{tabular}

Note: ${ }^{*} \mathrm{p}<0.05 ;{ }^{* *} \mathrm{p}<0.01 ;{ }^{* * *} \mathrm{p}<0.001$.

Table 3. The VIF of three models.

\begin{tabular}{cccc}
\hline & & AEM & \\
\cline { 2 - 4 } Variable & Equation (1) & Equation (2) & Equation (3) \\
UW & 1.11 & 1.12 & 1.16 \\
AUDIT & 1.11 & 1.11 & 1.9 \\
CASH & 1.85 & 1.85 & 1.77 \\
SIZE & 1.7 & 1.71 & 1.62 \\
LEV & 1.69 & 1.69 & 1.16 \\
GROWTH & 1.34 & 1.34 & \\
VC & 1.12 & 1.22 & 1.18 \\
UNION & & & \\
SINGLE & & &
\end{tabular}


Table 4. Jones modle and performance-match Jones model measure the accrul earnings management.

\begin{tabular}{|c|c|c|c|c|c|c|}
\hline & \multicolumn{3}{|c|}{ Jones (1991) model } & \multicolumn{3}{|c|}{ Kothari et al. (2005) performance-matched model } \\
\hline & Equation (1) & Equation (2) & Equation (3) & Equation (1) & Equation (2) & Equation (3) \\
\hline VC & -0.010 & & & -0.011 & & \\
\hline (T statistic) & $(-1.22)$ & & & $(-1.37)$ & & \\
\hline SINGLE & & $-0.021^{* *}$ & & & $-0.022^{* *}$ & \\
\hline (T statistic) & & $(-2.34)$ & & & $(-2.50)$ & \\
\hline UNION & & 0.001 & -0.001 & & -0.001 & -0.002 \\
\hline (T statistic) & & $(0.02)$ & $(-0.05)$ & & $(-0.12)$ & $(-0.16)$ \\
\hline AUDIT & 0.001 & 0.001 & 0.002 & 0.001 & 0.001 & -0.002 \\
\hline (T statistic) & $(0.11)$ & $(0.06)$ & $(0.22)$ & $(0.01)$ & $(-0.04)$ & $(-0.19)$ \\
\hline UW & 0.003 & 0.002 & 0.001 & 0.004 & 0.004 & 0.001 \\
\hline (T statistic) & $(0.40)$ & $(0.31)$ & $(0.16)$ & $(0.56)$ & $(0.47)$ & $(0.12)$ \\
\hline SIZE & -0.010 & -0.009 & -0.006 & -0.013 & -0.012 & -0.009 \\
\hline (T statistic) & $(-1.06)$ & $(-1.00)$ & $(-0.54)$ & $(-1.33)$ & $(-1.27)$ & $(-0.76)$ \\
\hline GROWTH & $0.035^{*}$ & $0.035^{* *}$ & $0.043^{* *}$ & $0.045^{* *}$ & $0.046^{* * *}$ & $0.048^{* *}$ \\
\hline (T statistic) & (1.89) & $(1.97)$ & $(2.05)$ & $(2.58)$ & $(2.63)$ & $(2.16)$ \\
\hline LEV & 0.007 & 0.006 & 0.021 & -0.016 & -0.017 & -0.007 \\
\hline (T statistic) & $(0.19)$ & $(0.17)$ & $(0.49)$ & $(-0.43)$ & $(-0.45)$ & $(-0.17)$ \\
\hline CASH & -0.008 & -0.001 & 0.019 & -0.100 & -0.092 & -0.081 \\
\hline (T statistic) & $(-0.12)$ & $(-0.01)$ & $(0.23)$ & $(-1.50)$ & $(-1.40)$ & $(-1.02)$ \\
\hline Constant & $0.311^{*}$ & $0.302^{*}$ & 0.281 & $0.366^{* *}$ & $0.358^{* *}$ & 0.352 \\
\hline (T statistic) & (1.73) & (1.69) & $(1.31)$ & $(2.02)$ & (1.99) & $(1.61)$ \\
\hline Number of Observations & 405 & 405 & 323 & 405 & 405 & 323 \\
\hline $\mathrm{R}^{2}$ & 0.096 & 0.103 & 0.125 & 0.125 & 0.131 & 0.140 \\
\hline Adjusted R-squared & 0.051 & 0.056 & 0.070 & 0.082 & 0.086 & 0.086 \\
\hline
\end{tabular}

Note: ${ }^{*} \mathrm{p}<0.05 ;{ }^{* *} \mathrm{p}<0.01 ;{ }^{* * *} \mathrm{p}<0.001$.

Compared with the non-VC-backed sample, accrual earnings management of the VC-backed sample is not significant lower.

Compared with the non-single-VC-backed sample, accrual earnings management of the single-VC-backed sample is significant lower (at the $5 \%$ level or higher). The result is robust even by different method measuring accrual earnings management.

Above all, it is reason to draw the following conclusions. In contrast to the non-VC-backed sample and the joint venture capital, the single venture capital has a significance negative correlation with the accrued earning management, which has inhibitive effect with it. However there is not significant negative correlation between the joint VC and accrued earning management.

\section{Conclusions}

In conclusion, there is the robus result: comparing the total sample which is divided into VC-backed IPO firms and non-VC-backed IPO firms IPO samples, the coefficient of the previous year's earnings management of VC-backed IPO firms is negative but it is not significant. 
Comparing the total sample which is divided into non-VC-backed IPO firms, single-VC-backed IPO firms and joint-VC-backed IPO firms samples, we found their effects on the previous year's earning management. The single-VC-backed IPO firms have a significantly lower accrued earning management than any one of the other two's. On the other hand, the joint-VC-backed IPO firms do not have a significantly lower accrued earning management. It means that single-VC-backed IPO firms have negative correlation with the previous year's earning management, but joint-VC-backed IPO firms do not.

\section{References}

[1] Patell, J.M. (1989) Discussion of On the Usefulness of Earnings and Earnings Research: Lessons and Directions from Two Decades of Empirical Research. Journal of Accounting Research, 193-201. http://dx.doi.org/10.2307/2491071

[2] Teoh, S.H., Wong, T.J. and Rao, G.R. (1998) Are Accruals during Initial Public Offerings Opportunistic? Review of Accounting Studies, 3, 175-208. http://dx.doi.org/10.1023/A:1009688619882

[3] Zhang, Z.Y. and Huang, X.J. (2003) Study on Earnings Management of IPO in China List Companies China. Soft Science, 10, 37-39.

[4] Gorman, M. and Sahlman, W.A. (1989) What Do Venture Capitalists Do? Journal of Business Venturing, 4, 231-248. http://dx.doi.org/10.1016/0883-9026(89)90014-1

[5] Barry, C.B., Muscarella, C.J., Peavy, J.W., et al. (1990) The Role of Venture Capital in the Creation of Public Companies: Evidence from the Going-Public Process. Journal of Financial Economics, 27, 447-471. http://dx.doi.org/10.1016/0304-405X(90)90064-7

[6] Jain, B.A. and Kini, O. (1995) Venture Capitalist Participation and the Post-Issue Operating Performance of IPO Firms. Managerial and Decision Economics, 16, 593-606. http://dx.doi.org/10.1002/mde.4090160603

[7] Campbell, T.L. and Frye, M.B. (2009) Venture Capitalist Monitoring: Evidence from Governance Structures. The Quarterly Review of Economics and Finance, 49, 265-282. http://dx.doi.org/10.1016/j.qref.2008.05.001

[8] Chahine, S. and Filatotchev, I. (2008) The Effects of Venture Capitalist Affiliation to Underwriters on Cohen D A, Dey A, Lys T Z. Real and Accrual-Based Earnings Management in the Pre- and Post-Sarbanes-Oxley Periods. The Accounting Review, 83, 757-787. http://dx.doi.org/10.2308/accr.2008.83.3.757

[9] Megginson, W.L. and Weiss, K.A. (1991) Venture Capitalist Certification in Initial Public Offerings. The Journal of Finance, 46, 879-903. http://dx.doi.org/10.1111/j.1540-6261.1991.tb03770.x

[10] Lin, T.H. and Smith, R.L. (1998) Insider Reputation and Selling Decisions: The Unwinding of Venture Capital Investments during Equity Ipos. Journal of Corporate Finance, 4, 241-263. http://dx.doi.org/10.1016/S0929-1199(98)00005-4

[11] Francis, B.B. and Hasan, I. (2001) The Underpricing of Venture and Nonventure Capital Ipos: An Empirical Investigation. Journal of Financial Services Research, 19, 99-113. http://dx.doi.org/10.1023/A:1011134715911

[12] Wang, C.F. and Li, J.D. (2003) Empirical Examination of Earnings Management by IPO Firms. Journal of Tianjin University (Social Sciences), 5, 324-328.

[13] Wang, Z.Q. and Liu, X. (2003) Study on IPO Earnings Management and Subsequent Performance. Economic Management Journal, 18, 78-81.

[14] Cai, C., Li, M. and He, H. (2013) Constraint Condition IPO Earnings Management and Performance-Viewpoint from Accruals and Real Earnings Management. Accounting Research, 10, 35-42, 96.

[15] Qi, H.J. and Huang, Y.W. (2014) Accrual and Real Earnings Management and the Strategies Before and after the IPO: Samples of A-Share Listed Corporation from 2007 to 2011. Reform, No. 3, 130-141.

[16] Amit, R., Brander, J. and Zott, C. (1998) Why Do Venture Capital Firms Exist? Theory and Canadian Evidence. Journal of Business Venturing, 13, 441-466. http://dx.doi.org/10.1016/S0883-9026(97)00061-X

[17] Arthurs, J.D. and Busenitz, L.W. (2006) Dynamic Capabilities and Venture Performance: The Effects of Venture Capitalists. Journal of Business Venturing, 21, 195-215. http://dx.doi.org/10.1016/j.jbusvent.2005.04.004

[18] Hochberg, Y. (2004) Venture Capital and Corporate Governance in the Newly Public Firm. Cornell University, Ithaca.

[19] Morsfield, S.G. and Tan, C.E.L. (2006) Do Venture Capitalists Influence the Decision to Manage Earnings in Initial Public Offerings? The Accounting Review, 81, 1119-1150. http://dx.doi.org/10.2308/accr.2006.81.5.1119

[20] Gioielli, S. and De Carvalho, A.G. (2008) The Dynamics of Earnings Management in IPOs and the Role of Venture Capital. Available at SSRN 1134932.

[21] Agrawal, A. and Cooper, T. (2010) Accounting Scandals in IPO Firms: Do Underwriters and VCs Help? Journal of Economics \& Management Strategy, 19, 1117-1181. http://dx.doi.org/10.1111/j.1530-9134.2010.00279.x 
[22] Chen, X.Y. (2010) Empirical Research On Venture Capital and Earnings Management of IPO Firms. Research on Financial and Economic Issues, 1, 64-69.

[23] Lee, G. and Masulis, R.W. (2011) Do More Reputable Financial Institutions Reduce Earnings Management by IPO Issuers? Journal of Corporate Finance, 17, 982-1000. http://dx.doi.org/10.1016/j.jcorpfin.2011.04.012

[24] Lerner, J. (1994) The Syndication of Venture Capital Investments. Financial Management, 23, 16-27.

[25] Sorenson, O. and Stuart, T.E. (2008) Bringing the Context Back in: Settings and the Search for Syndicate Partners in Venture Capital Investment Networks. Administrative Science Quarterly, 53, 266-294. http://dx.doi.org/10.2189/asqu.53.2.266

[26] Filatotchev, I., Wright, M. and Arberk, M. (2006) Venture Capitalists, Syndication and Governance in Initial Public Offerings. Small Business Economics, 26, 337-350. http://dx.doi.org/10.1007/s11187-005-2051-3

[27] Cumming, D.J. (2006) The Determinants of Venture Capital Portfolio Size: Empirical Evidence. Journal of Business, 79, 1083-1126. http://dx.doi.org/10.1086/500670

[28] Chahine, S., Arthurs, J.D., Filatotchev, I., et al. (2012) The Effects of Venture Capital Syndicate Diversity on Earnings Management and Performance of IPOs in the US and UK: An Institutional Perspective. Journal of Corporate Finance, 18, 179-192. http://dx.doi.org/10.1016/j.jcorpfin.2011.11.007

[29] Dechow, P.M., Sloan, R.G. and Sweeney, A.P. (1995) Detecting Earnings Management. Accounting Review, 70, 193-225.

[30] Wu, C.P., Wu, S.N., Cheng, J.Y. and Wang, L. (2012) The Role of Venture Capital in the Investment and Financing Behavior of Listed Companies: Evidence from China. Economic Research Journal, No. 1, 105-119, 160.

[31] Li, X. and Nie, L.J. (2006) Audit Quality and Earnings Management for China IPO Firms. Auditing Research, No. 6, 67-72.

[32] Jones, J.J. (1991) Earnings Management during Import Relief Investigations. Journal of Accounting Research, 29, 193-228. http://dx.doi.org/10.2307/2491047

[33] Kothari, S.P., Leone, A.J. and Wasley, C.E. (2005) Performance Matched Discretionary Accrual Measures. Journal of Accounting and Economics, 39, 163-197. http://dx.doi.org/10.1016/j.jacceco.2004.11.002 